Article

\title{
Optimization of Protective Agents for The Freeze-Drying of Paenibacillus polymyxa Kp10 as a Potential Biofungicide
}

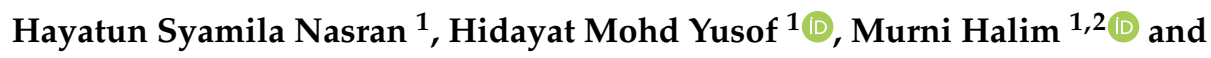 \\ Nor'Aini Abdul Rahman 1,2,* \\ 1 Department of Bioprocess Technology, Faculty of Biotechnology and Biomolecular Sciences, Universiti Putra \\ Malaysia, Serdang, Selangor 43400, Malaysia; hayatun.nasran@gmail.com (H.S.N.); \\ hidayatmy@gmail.com (H.M.Y.); murnihalim@upm.edu.my (M.H.) \\ 2 Bioprocessing and Biomanufacturing Research Centre, Faculty of Biotechnology and Biomolecular Sciences, \\ Universiti Putra Malaysia, Serdang, Selangor 43400, Malaysia \\ * Correspondence: nor_aini@upm.edu.my
}

Received: 19 February 2020; Accepted: 14 April 2020; Published: 4 June 2020

check for updates

\begin{abstract}
Anthracnose is a fungal disease causing major losses in crop production. Chemical fungicides widely used in crop plantations to combat fungal infections can be a threat to the environment and humans in the long term. Recently, biofungicides have gained much interest as an alternative to chemical fungicides due to their environmentally friendly nature. Biofungicide products in powder form can be formulated using the freeze-drying technique to provide convenient storage. Protective agent formulation is needed in maintaining the optimal viable cells of biofungicide products. In this study, $8.10 \log$ colony-forming unit (CFU)/mL was the highest cell viability of Paenibacillus polymyxa Kp10 at $22 \mathrm{~h}$ during incubation. The effects of several selected protective agents on the viability of P. polymyxa Kp10 after freeze-drying were studied. Response surface methodology (RSM) was used for optimizing formulation for the protective agents. The combination of lactose $(10 \% w / v)$, skim milk $(20 \% w / v)$, and sucrose $(27.5 \% w / v)$ was found to be suitable for preserving P. polymyxa Kp10 during freeze-drying. Further, P. polymyxa Kp10 demonstrated the ability to inhibit fungal pathogens, Colletotrichum truncatum and C. gloeosporioides, at $60.18 \%$ and $66.52 \%$ of inhibition of radial growth, respectively.
\end{abstract}

Keywords: antimicrobial; antifungal; biofungicide; optimization; Paenibacillus polymyxa; RSM

\section{Introduction}

Anthracnose is a common disease caused by fungal pathogens affecting crops' yield and fruit quality [1]. Colletotrichum capsici, C. gloeosporioides, and C. acutatum have been reported as pathogens causing chili anthracnose [2]. Conventional fungicide is a chemical substance commonly used in crop plantations to combat fungal diseases. However, the unregulated use of chemical fungicides can be detrimental to public health especially to people that consume crops as a fiber source. Moreover, the excessive use of chemical fungicides can also contribute to environmental problems through the contamination of groundwater where fungicides are absorbed into the soil [3]. Therefore, an urgent strategic approach is needed to replace the presently used fungicides. Biocontrol agents, defined as the use of an organism to reduce the population of another organism, have now been introduced to replace the harmful chemical pesticides [3]. For successful commercializing of biocontrol agents, some product development strategies including preservation steps have to be implemented for maintaining high cell viability throughout the process. 
Paenibacillus species has the ability to be applied as an alternative biocontrol agent to the current chemical pesticides against plant pathogens. The species produces substances that can be used as pesticides and utilized for bioremediation agents. For instance, Paenibacillus polymyxa strains possess potential antagonistic activity, where they can secrete antimicrobial compounds that demonstrate a spectrum of activity against fungi, bacteria, and nematodes [4,5]. Further, P. polymyxa strains were reported to produce a range of antibiotics such as polymyxin, polypeptins, and jolipeptin, which effectively work against bacteria, and also produced gatavalin and fusaricidin against fungi [6,7]. In addition, they offer protection against various insect herbivores and phytopathogens by triggering a hypersensitive defensive response of the plant, known as induced systemic resistance [8]. P. polymyxa strain (HY96-2) isolated from a tomato rhizosphere has proven to control tomato bacteria wilt and provide beneficial effects in promoting tomato plants' growth [9]. Likewise, P. polymyxa NSY50 isolated from vinegar waste compost was identified as a potential biocontrol agent for controlling Fusarium wilt, a major destructive soil-borne disease infecting cucumber [10]. Furthermore, Paenibacillus also has the potential as a biocontrol for food-borne bacteria including Salmonella [11]. Putting the wide antagonistic activity features of P. polymyxa into consideration, this species could be the best candidate for biofungicide.

The success in commercializing bacterial strains as a potential biofungicide is highly dependent on preservation technologies employed by industrial companies. Suitable preservation methods could maintain high cell viability not only during the preservation process but most importantly during the long-term product storage [12]. Since bacteria have vulnerable characteristics, freeze-drying under vacuum or lyophilization is often considered as one of the proper preservation methods of the cells. The freeze-drying technique begins with the frozen step followed by primary drying through sublimation and desorption as the second drying stage $[13,14]$.

Several factors affect the viability of cells during the freeze-drying process. In general, freeze-drying may cause two different stresses onto the cells. The first is where the cells are frozen and water molecules in the cells are disabled followed by a drying stage where water molecules are removed [15]. Ice formation in the cells during the freezing phase could cause damage to the cells due to membrane rupture [16]. To overcome these effects, protective agents are usually added before freezing or freeze-drying stage $[17,18]$. However, there are many other factors affecting bacteria survival such as intrinsic factors that include bacteria morphology [19], growth medium used during bacteria culture [20], bacteria survival during the culture environment [21,22], and storage conditions after preservation [23]. Thus, this present study aims to optimize the protective agents for P. polymyxa Kp10 subjected to freeze-drying using response surface methodology (RSM) to obtain the optimal number of cells after the freeze-drying process and to investigate the biofungicide potential of P. polymyxa Kp10 against fungal phytopathogen which commonly affects crop production.

\section{Results and Discussion}

\subsection{Cell Growth Curve of P. polymyxa Kp10}

Figure 1 shows that the highest cell viability of P. polymyxa Kp10 was 8.10 log colony-forming unit (CFU)/mL attained at $22 \mathrm{~h}$ of the incubation period. The cell growth started to gradually decrease at $24 \mathrm{~h}$ with its cell viability at $8.03 \log \mathrm{CFU} / \mathrm{mL}$. According to Keivani et al. [24], bacteria are more resistant in the stationary phase since they develop general stress resistance due to nutrient exhaustion compared to bacteria conditions in the log phase. P. polymyxa GBR-1 also has its maximum cell viability between 20-28 $\mathrm{h}$ after incubation [25]. In general, the survival rate of cells depends largely on the type of organisms. In an earlier report, Lactobacillus rhamnosus at the stationary phase gave the highest recovery rate (31\%-50\%) after drying compared to the cells at the early log phase with $14 \%$ survival rate [26]. Likewise, Rhizobia cells from stationary phase achieved higher cell viability compared to those in the $\log$ phase [27]. Thus, in this particular work, $8.10 \log$ CFU/mL of cells harvested at $22 \mathrm{~h}$ are 
considered as a suitable number for an initial cell concentration to be subjected to freeze-drying for minimizing the possible cell loss after the freeze-drying process.

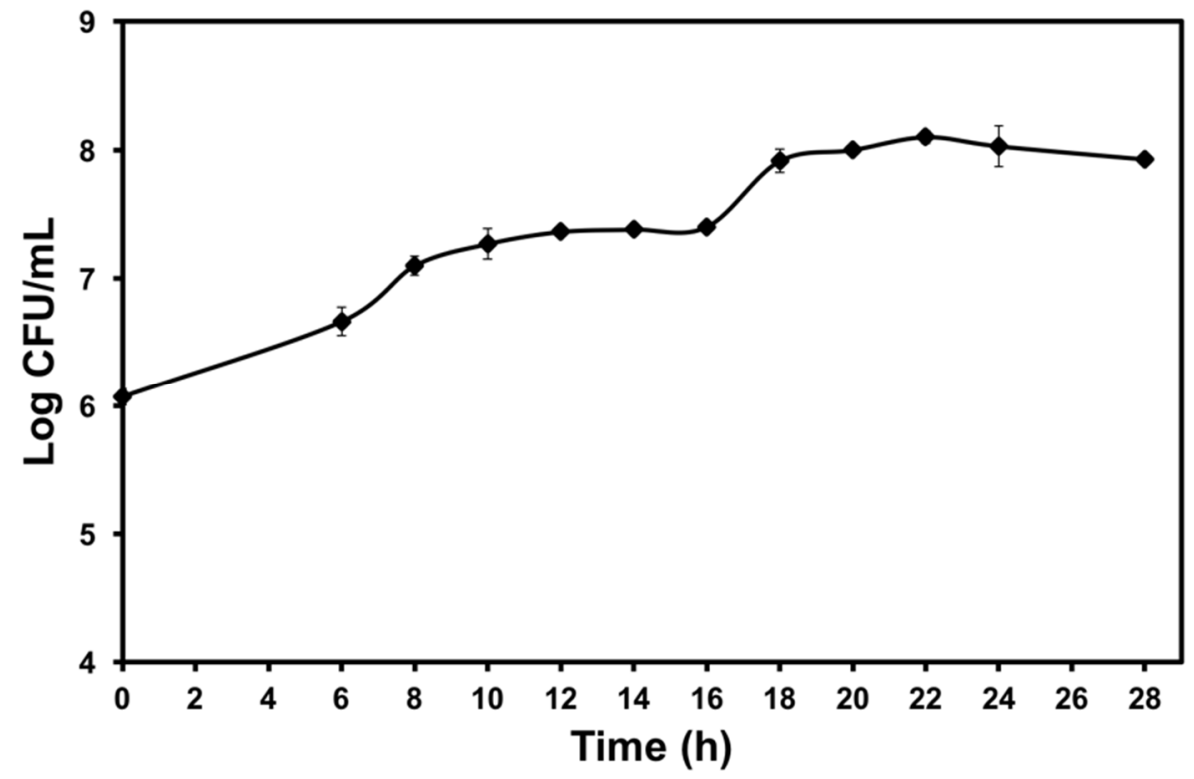

Figure 1. A growth profile of P. polymyxa Kp10 based on colony-forming unit (CFU)/mL ( $\downarrow)$ during $28 \mathrm{~h}$ of the incubation period. The error bars represent the standard deviations about the mean $(n=3)$.

\subsection{Selection of Protective Agents for Bioformulation of P. polymyxa Kp10}

Skim milk was shown as the most suitable protectant agent for P. polymyxa Kp10 cells in maintaining high cell viability compared to control and Soytone (Table 1). Skim milk $(20 \% w / v)$ provided the highest protection for cell survival at $89.26 \%$ followed by lactose $(10 \% w / v)$ with $87.78 \%$ survival rate. Skim milk is one of the most preferable protective agents and widely studied for freeze-drying of various types of bacteria [16,28-30]. Proteins and calcium in the skim milk may contribute to cell protection from the extreme and harsh conditions of the freeze-drying process by forming a protective coating on the cell wall [31]. Sucrose provides $83.14 \%$ survival rate of P. polymyxa Kp10 as the protective agent. Hubalek [32] suggested that sucrose at the concentration of $10 \%(w / v)$ is the most frequently used for microorganism lyophilization. Meanwhile, Ming et al. [16] used sucrose at 20\% $(w / v)$ for freeze-drying L. salivarius I 24 and obtained a considerably high cell survival rate of $9.0 \%$.

Table 1. Effect of protective agents on cell viability of $P$. polymyxa Kp10 before and after freeze-drying.

\begin{tabular}{cccc}
\hline \multirow{2}{*}{ Protective Agent } & \multicolumn{2}{c}{ Viable Cell (log CFU/mL) } & \multirow{2}{*}{ Survival Rate (\%) } \\
\cline { 2 - 3 } & $*$ Before Freeze Drying & After Freeze Drying & \\
\hline Skim milk $(20 \% w / v)$ & 8.050 & 7.185 & 89.26 \\
Lactose $(10 \% w / v)$ & 8.000 & 7.022 & 87.78 \\
Sucrose $(30 \% w / v)$ & 8.097 & 6.732 & 83.14 \\
Soytone $(15 \% w / v)$ & 7.574 & 5.236 & 69.13 \\
Distilled water (control) & 7.468 & 4.648 & 62.24 \\
\hline
\end{tabular}

* After the cell pellets mixed with the protective agents.

As expected, distilled water that was used as a control for the protective agents' selection for P. polymyxa Kp10 recorded a very low survival rate (62.24\%) as there was no protection of the cells during lyophilization. A similar result was observed when Soytone $(69.13 \% w / v)$ was used as the protective agent in which only a $0.46 \%$ survival rate was recorded after freeze-drying. Likewise, Portner et al. [33] reported that 10\% (w/v) Soytone gave less optimal protection for Campylobacter jejuni 
as a protective agent during freeze-drying. Based on this study, skim milk, lactose, and sucrose were the preferred protective agents for P. polymyxa Kp10 and thus they were chosen for the subsequent optimization study.

\subsection{Optimization of Protective Agent Combination Using RSM}

Protective agent combinations were discovered based on a five-level two-variable central composite design as shown in Table 6, which comprised the actual factor level corresponding to coded factor levels. Regression analysis was used on experimental data and several prediction models are shown in Table 2.

Table 2. A sequential model sum of squares.

\begin{tabular}{|c|c|c|c|c|c|c|}
\hline & Sum of Squares & df & Mean Square & F-Value & $\begin{array}{c}p \text {-Value } \\
(\text { Prob > F })\end{array}$ & \\
\hline Mean vs. Total & 661.95 & 1 & 661.95 & & & \\
\hline Linear vs. Mean & $2.590 \times 10^{-4}$ & 3 & $8.632 \times 10^{-5}$ & 0.022 & 0.9954 & \\
\hline 2FI vs. Linear & $4.605 \times 10^{-3}$ & 3 & $1.535 \times 10^{-3}$ & 0.34 & 0.7960 & \\
\hline Quadratic vs. 2FI & 0.058 & 3 & 0.019 & 505.45 & $<0.0001$ & Suggested \\
\hline Cubic vs. Quadratic & $1.940 \times 10^{-4}$ & 4 & $4.851 \times 10^{-5}$ & 1.54 & 0.3032 & Aliased \\
\hline Residual & $1.892 \times 10^{-4}$ & 6 & $3.154 \times 10^{-5}$ & & & \\
\hline Total & 662.02 & 20 & 33.10 & & & \\
\hline
\end{tabular}

ANOVA illustrated that the optimization of protective agent combination was most preferably described to the quadratic model as shown in Table 3. ANOVA shows a lack of fit that was not significant $(p>0.05)$, hence defining that the models are significant and can be used for optimization. The $F$-value for the model was 182.58 , which was significant. $A B, A C, B C, A^{2}, B^{2}$, and $C^{2}$ were the significant model terms. Model terms of A, B, and C were not significant since their $p$-value $($ Prob $>F)$ were more than 0.05. Lack of fit was not significant with the value of 3.52 . There was a $9.68 \%$ chance that lack of fit value could happen because of noise. In determining the fitness of the model, the model must have the significance of the model $(p<0.05)$ and the insignificance of the lack of fit $(p>0.05)$ [34]. Fitness between the development model and experimental data can be determined based on the coefficient value $\left(\mathrm{R}^{2}\right)$. In this study, $\mathrm{R}^{2}$ was equal to 0.9940 , implying low error in the model.

Table 3. Analysis of variance (ANOVA) and model coefficients.

\begin{tabular}{|c|c|c|c|c|c|c|}
\hline Source & Sum of Squares & df & Mean Square & $F$ value & $\begin{array}{c}p \text {-Value } \\
(\text { Prob }>F)\end{array}$ & \\
\hline Model & 0.063 & 9 & $6.998 \times 10^{-3}$ & 182.58 & $<0.0001$ & \multirow[t]{11}{*}{ Significant } \\
\hline A-sucrose & $1.231 \times 10^{-4}$ & 1 & $1.231 \times 10^{-4}$ & 3.21 & 0.1034 & \\
\hline B-skim milk & $9.761 \times 10^{-6}$ & 1 & $9.761 \times 10^{-6}$ & 0.25 & 0.6247 & \\
\hline C-lactose & $1.261 \times 10^{-4}$ & 1 & $1.261 \times 10^{-4}$ & 3.29 & 0.0998 & \\
\hline AB & $3.001 \times 10^{-4}$ & 1 & $3.001 \times 10^{-4}$ & 7.83 & 0.0189 & \\
\hline AC & $4.005 \times 10^{-3}$ & 1 & $4.005 \times 10^{-3}$ & 104.49 & $<0.0001$ & \\
\hline BC & $3.001 \times 10^{-4}$ & 1 & $3.001 \times 10^{-4}$ & 7.83 & 0.0189 & \\
\hline $\mathrm{A}^{2}$ & 0.017 & 1 & 0.017 & 435.37 & $<0.0001$ & \\
\hline$B^{2}$ & 0.015 & 1 & 0.015 & 399.93 & $<0.0001$ & \\
\hline$C^{2}$ & 0.037 & 1 & 0.037 & 957.67 & $<0.0001$ & \\
\hline Residual & $3.833 \times 10^{-4}$ & 10 & $3.833 \times 10^{-5}$ & \multirow{4}{*}{3.52} & \multirow{4}{*}{0.0968} & \\
\hline Lack of Fit & $2.985 \times 10^{-4}$ & 5 & $5.969 \times 10^{-5}$ & & & \multirow[t]{3}{*}{$\begin{array}{c}\text { Not } \\
\text { significant }\end{array}$} \\
\hline Pure Error & $8.483 \times 10^{-5}$ & 5 & $1.697 \times 10^{-5}$ & & & \\
\hline Cor Total & 0.063 & 19 & & & & \\
\hline
\end{tabular}

Figure 2 shows the response surface curves plotted in function of two factors while the third was maintained constant at its main level. Based on the three graphs plotted in Figure 2, the maximum 
cell viability after freeze-drying was predicted at $5.839 \log \mathrm{CFU} / \mathrm{mL}$ when lactose $(10 \% w / v)$, sucrose $(27.5 \% w / v)$, and skim milk $(20 \% w / v)$ were used as the combined protective agents for P. polymyxa Kp10. This suggests that the combination of lactose and sucrose could give a synergetic effect in protecting the cells during the process. In addition, it can be seen that the combinations from the selected protective agents provided a synergic effect in maintaining high cell viability after the freeze-drying process. Sucrose was reported to replace water around polar residues in macromolecular, thus stabilizing cell membranes and proteins during desiccation [35]. Sugars from disaccharides could preserve cell structure by hydrogen bond formation that maintains tertiary protein structure when water molecules are absent [36]. Meanwhile, skim milk rich in protein is capable of preventing cells from injury caused by extracellular ice formation during the freezing stage by providing a protective coat to the cells [32]. The survival rate of cells after freeze-drying for lactose $(10 \% w / v)$ and sucrose $(27.5 \% w / v)$ was $83 \%$. According to Wong et al. [37], 71.65\%-82.07\% of survival rates can be obtained when using different skim milk and sugar combinations as protectants. This supported the survival rate of L. salivarius at $83 \%-85 \%$ when a combination of skim milk, trehalose, and sucrose was used as a protective agent [37]. In this study, a combination of skim milk, sucrose, and lactose gave a significant effect on cell viability after the freeze-drying process by maintaining maximum cell viability.

a

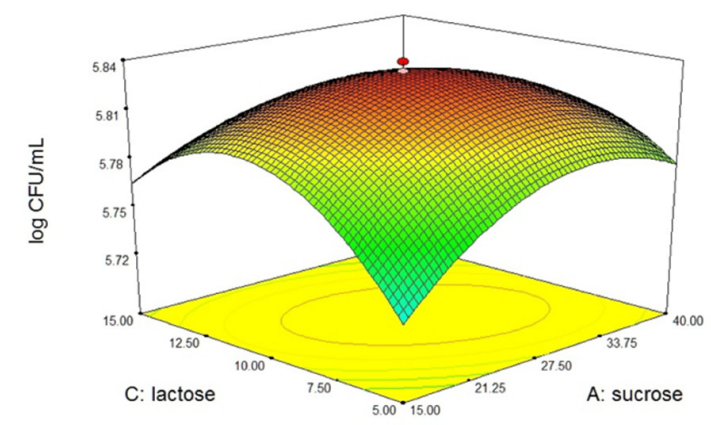

b

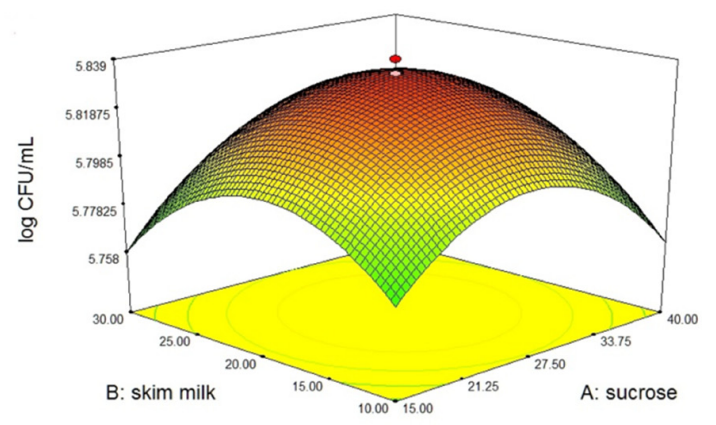

C

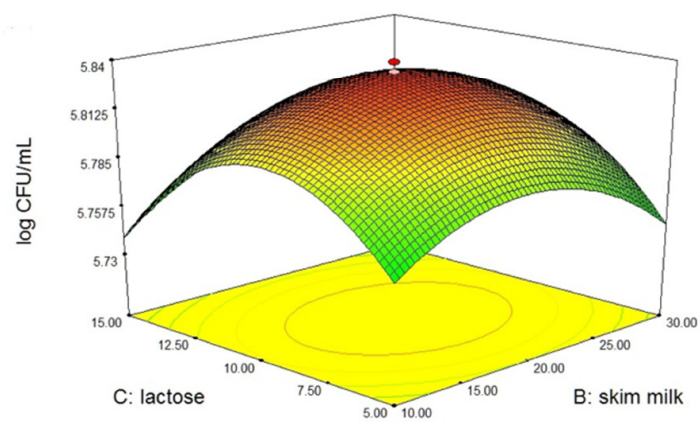

Figure 2. Response surface plots for cell viability of P. polymyxa Kp10 affected by (a) lactose (10\% w/v) and sucrose $(27.5 \% w / v) ;(\mathbf{b})$ skim milk $(20 \% w / v)$ and sucrose $(27.5 \% w / v)$; and (c) lactose $(10 \% w / v)$ and skim milk $(20 \% w / v)$ as protective agents subjected to freeze-drying.

\subsection{Antifungal Activity}

In this study, P. polymyxa Kp10 showed in vitro antifungal activity against the tested pathogens (Figure 3). As shown in Table 4, P. polymyxa Kp10 showed inhibitory effects in all the tested fungal pathogens with different efficacy. The dual cultures were incubated for five days and none of the fungal pathogens overlaid the bacterial colony. From the results, the highest percentage of inhibition of radial growth (PIRG) value $(66.52 \%)$ was the freeze-dried P. polymyxa Kp10 against Colletotrichum gloeosporioides, while lowest PIRG value (60.18\%) of freeze-dried P. polymyxa Kp10 against 
C. truncatum was recorded. The non-freeze-dried P. polymyxa Kp10 also demonstrated antifungal activity (Table 4 ) with PIRG values of $62.80 \%$ and $60.11 \%$ against C. truncatum and C. gloeosporioides, respectively. Likewise, Song et al. [38] reported that freeze-dried sulphate-reducing bacteria showed higher enzymatic activity in sulphate $\left(\mathrm{SO}_{4}{ }^{-}\right)$reduction compared to the fresh culture. Our findings were in accordance with several other studies on the antifungal activity performed by Paenibacillus species [8,39,40]. Jeong et al. [41] reported that P. polymyxa E681 produced an antibiotic known as polymyxin. Further, Karpunina et al. [42] proved that P. polymyxa 1460 has the ability to produce metabolites called lectins. Lectins are recognized to enhance cellulose degradation in plant cells and increase $\beta$-glucosidase activity in the wheat root cell wall. Moreover, most of the antimicrobial substances produced by P. polymyxa are peptides [40]. Meanwhile, P. polymyxa strains WR-2 and SQR-21 produced high $\beta$-1.3-glucanase when stimulated by the low concentration of uric acid produced by fungus Fusarium oxysporum [43]. Further, Paenibacillus strain producing a hydrolytic enzyme was also used for attacking a fungal cell wall containing $\beta-1.3$-glucan, chitin, and $11 \%$ protein [8].

a
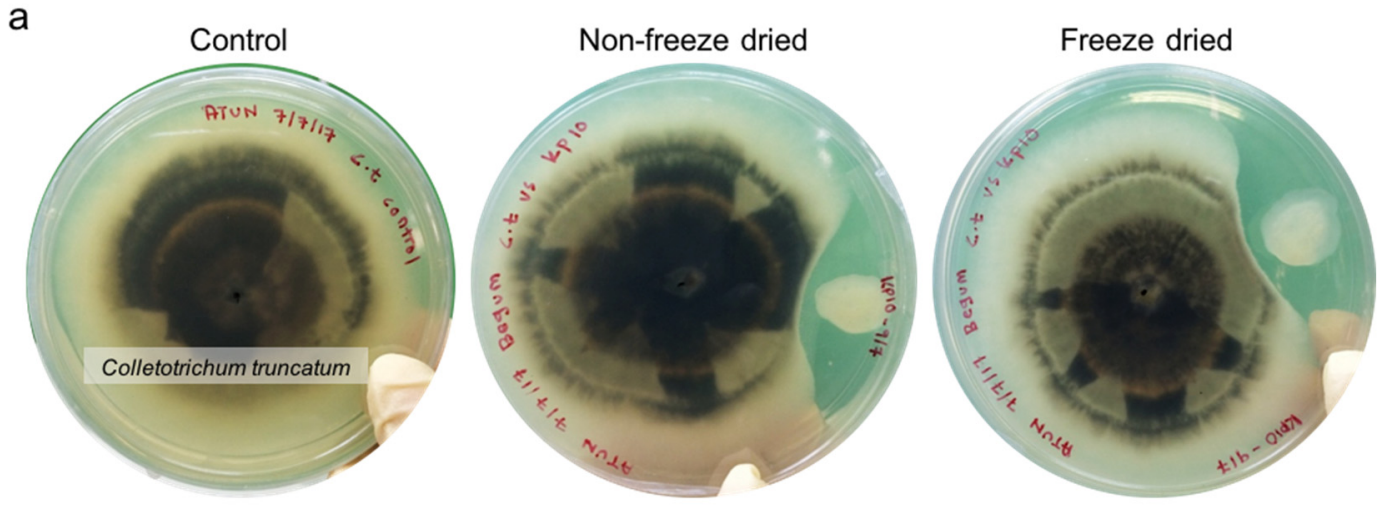

b
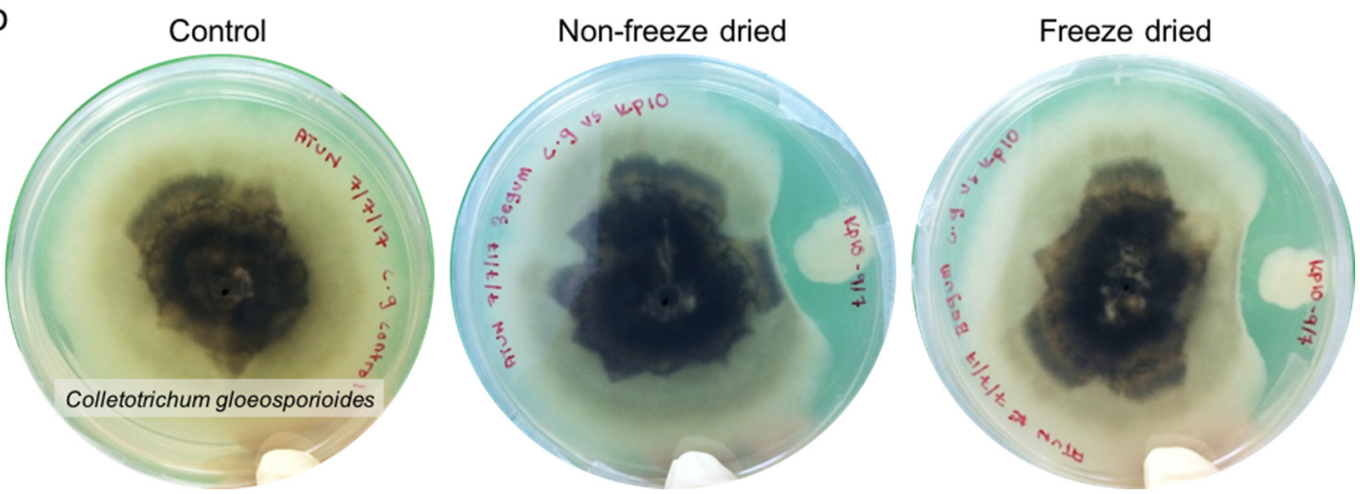

Figure 3. In vitro antifungal activity of P. polymyxa Kp10 against (a) C. truncatum and (b) C. gloeosporioides.

Table 4. Antifungal activity of non-freeze-dried and freeze-dried P. polymyxa Kp10 against fungal pathogens in dual culture after five days growth.

\begin{tabular}{ccccc}
\hline \multirow{2}{*}{ Fungal Pathogen } & \multicolumn{2}{c}{ Non-Freeze-Dried } & \multicolumn{2}{c}{ Freeze-Dried } \\
\cline { 2 - 5 } & $\begin{array}{c}\text { Inhibition } \\
\text { Distance }(\mathbf{m m})\end{array}$ & $\begin{array}{c}\text { Antagonism } \\
\text { (PIRG) }\end{array}$ & $\begin{array}{c}\text { Inhibition } \\
\text { Distance (mm) }\end{array}$ & $\begin{array}{c}\text { Antagonism } \\
\text { (PIRG) }\end{array}$ \\
\hline $\begin{array}{c}\text { Colletotrichum } \\
\text { truncatum } \\
\begin{array}{c}\text { Colletotrichum } \\
\text { gloeosporioides }\end{array}\end{array}$ & 13.03 & $62.80 \%$ & 13.95 & $60.18 \%$ \\
\hline
\end{tabular}

Note: Radius of C. truncatum and C. gloeosporioides without P. polymyxa Kp10 (control) were $35.03 \mathrm{~mm}$ and $37.10 \mathrm{~mm}$, respectively. PIRG: percentage of inhibition of radial growth. 


\section{Materials and Methods}

\subsection{Microorganism and Cell Growth Curve Preparation}

The bacterium, P. polymyxa Kp10, used in this study was provided by Bioprocessing and Biomanufacturing Research Centre (BBRC), Universiti Putra Malaysia, Serdang. The strain was stored at $-80{ }^{\circ} \mathrm{C}$ in $20 \%(v / v)$ glycerol as stock cultures. The strain was grown on an M17 agar plate and incubated for $48 \mathrm{~h}$ at $37^{\circ} \mathrm{C}$. A colony from the plate was picked and placed into $10 \mathrm{~mL}$ of M17 broth in a $15 \mathrm{~mL}$ centrifuge tube, then incubated at $37^{\circ} \mathrm{C}$ for $18 \mathrm{~h}$. The culture was used as inoculum culture for cell growth analysis. The culture was inoculated (5\%) into M17 broth (100 mL) and incubated at $37^{\circ} \mathrm{C}$ for $28 \mathrm{~h}$ at $150 \mathrm{rpm}$. Samples were collected starting at $6 \mathrm{~h}$ and sampled for every $2 \mathrm{~h}$ after until it stopped at $28 \mathrm{~h}$. The number of cells is recorded as the average of the colony-forming unit $(\log \mathrm{CFU} / \mathrm{mL})$ which is referred to as cell viability [22] and was used to plot the growth curve vs. the incubation time. The sampling was performed in triplicate.

\subsection{Protective Agents Screening and Preparation of Protective Agents}

Skim milk, lactose, sucrose, and Soytone were used as protective agents and distilled water was used as a control. In this study, all the protective agents were freshly prepared. The protective agents were autoclaved for $5 \mathrm{~min}$ at $121^{\circ} \mathrm{C}$. Skim milk $(20 \% w / v)$, lactose $(10 \% w / v)$, sucrose $(30 \% w / v)$ and Soytone $(15 \% w / v)$ were screened as the protective agents. The selection of the protective agents was based on the survival rate of the cell after freeze-drying in the preliminary experiments of this study (data shown in Table 1). The selected protective agents were identified by a central composite design (CCD). Table 5 displays all 20 different combinations of the selected protective agents for optimization.

Table 5. Protective agent combination based on a central composite design (CCD).

\begin{tabular}{ccccc}
\hline \multirow{2}{*}{ Run } & Type & Factor $\mathbf{1}\left(\mathbf{X}_{\mathbf{1}}\right)$ & Factor 2 $\left.\mathbf{X}_{\mathbf{2}}\right)$ & Factor $\left.\mathbf{3} \mathbf{X}_{\mathbf{3}}\right)$ \\
\cline { 3 - 5 } & & Sucrose & Skim Milk & Lactose \\
\hline $\mathbf{1}$ & Center & $0(27.5 \%)$ & $0(20 \%)$ & $0(10 \%)$ \\
$\mathbf{2}$ & Center & $0(27.5 \%)$ & $0(20 \%)$ & $0(10 \%)$ \\
$\mathbf{3}$ & Center & $0(27.5 \%)$ & $0(20 \%)$ & $0(10 \%)$ \\
$\mathbf{4}$ & Center & $0(27.5 \%)$ & $0(20 \%)$ & $0(10 \%)$ \\
$\mathbf{5}$ & Center & $0(27.5 \%)$ & $0(20 \%)$ & $0(10 \%)$ \\
$\mathbf{6}$ & Center & $0(27.5 \%)$ & $0(20 \%)$ & $0(10 \%)$ \\
$\mathbf{7}$ & Axial & $0(27.5 \%)$ & $0(20 \%)$ & $1.682(18 \%)$ \\
$\mathbf{8}$ & Axial & $0(27.5 \%)$ & $0(20 \%)$ & $-1.682(2 \%)$ \\
$\mathbf{9}$ & Axial & $-1.682(6.48 \%)$ & $0(20 \%)$ & $0(10 \%)$ \\
$\mathbf{1 0}$ & Axial & $1.682(48.52 \%)$ & $0(20 \%)$ & $0(10 \%)$ \\
$\mathbf{1 1}$ & Axial & $0(27.5 \%)$ & $1.682(37 \%)$ & $0(10 \%)$ \\
$\mathbf{1 2}$ & Fact & $0(27.5 \%)$ & $-1.682(3 \%)$ & $0(10 \%)$ \\
$\mathbf{1 3}$ & Fact & $-1(15 \%)$ & $1(30 \%)$ & $-1(5 \%)$ \\
$\mathbf{1 4}$ & Fact & $1(40 \%)$ & $-1(10 \%)$ & $1(15 \%)$ \\
$\mathbf{1 5}$ & Fact & $-1(15 \%)$ & $-1(10 \%)$ & $-1(5 \%)$ \\
$\mathbf{1 6}$ & Fact & $1(40 \%)$ & $1(30 \%)$ & $1(15 \%)$ \\
$\mathbf{1 7}$ & Fact & $-1(15 \%)$ & $-1(10 \%)$ & $1(15 \%)$ \\
$\mathbf{1 8}$ & Fact & $-1(15 \%)$ & $1(30 \%)$ & $1(15 \%)$ \\
$\mathbf{1 9}$ & Fact & $1(40 \%)$ & $-1(10 \%)$ & $-1(5 \%)$ \\
$\mathbf{2 0}$ & Fact & $1(40 \%)$ & $1(30 \%)$ & $-1(5 \%)$ \\
\hline
\end{tabular}

\subsection{Experimental Design for Optimization of Protective Agent Combination Using RSM}

In this study, the considered cell viability of P. polymyxa Kp10 after freeze-drying was mainly affected by types and concentrations of the protective agent. To determine the optimal protective agent combination, the ranges of skim milk concentration $(10 \%-30 \% w / v)$, lactose $(5 \%-15 \% w / v)$, 
and sucrose $(15 \%-40 \% w / v)$ were chosen based on the previous preliminary test and several other reported studies $[11,28,30,40]$.

A five-level two-variable (Table 5) CCD with three replicates at the center point was conducted to determine the optimum combination of protective agents using RSM. Cell viability of P. polymyxa Kp10 was used as a response for the experiments. Analysis of variance (ANOVA) was used for regression analysis of variance. Table 6 depicts that each factor in the CCD was used at different levels $(-1.1682$, $-1,0,1,1.682)$. In performing the regression analysis and graphical experiments, Design Expert ${ }^{\circledR}$ software version 7.0.0 (Stat-ease Inc, Minneapolis, MN, USA) was used.

Table 6. Actual factor levels corresponding to coded factor levels for three variables.

\begin{tabular}{ccccccc}
\hline \multirow{2}{*}{ Factor } & \multirow{2}{*}{ Symbol } & \multicolumn{5}{c}{ Actual Factor Level at Coded Factor of } \\
\cline { 3 - 7 } & & $\mathbf{- 1 . 6 8 2}$ & $\mathbf{- 1}$ & $\mathbf{0}$ & $\mathbf{1}$ & $\mathbf{1 . 6 8 2}$ \\
\hline Skim milk (\%) & $\mathrm{X}_{1}$ & 3.18 & 10.00 & 20.00 & 30.00 & 36.82 \\
Lactose (\%) & $\mathrm{X}_{2}$ & 1.59 & 5.00 & 10.00 & 15.00 & 18.41 \\
Sucrose (\%) & $\mathrm{X}_{3}$ & 6.48 & 15.00 & 27.50 & 40.00 & 48.52 \\
\hline
\end{tabular}

\subsection{Culture Preparation for Freeze-Drying}

The strain was inoculated at $5 \%(v / v)$ in fresh M17 broth $(500 \mathrm{~mL})$ in a $1 \mathrm{~L}$ Erlenmeyer flask incubated at $37^{\circ} \mathrm{C}$ for $22 \mathrm{~h}$ at $150 \mathrm{rpm}$. Cells were harvested by centrifugation within $22 \mathrm{~h}$ at $10,000 \times g$ for $15 \mathrm{~min}$ at $4{ }^{\circ} \mathrm{C}$. The supernatants were discarded, and the cell pellets were washed once with sterilized $0.02 \mathrm{M}$ phosphate buffer, $\mathrm{pH}$ 7.2. The cell pellets were centrifuged again before they were resuspended in different combinations of sterile protective agents. Then, $2 \mathrm{~mL}$ of bacterial suspension was placed in a $5 \mathrm{~mL}$ sterilized vial in triplicate and kept at $-28{ }^{\circ} \mathrm{C}$ for $18 \mathrm{~h}$. The frozen samples were desiccated in a pilot-scale freeze-dryer machine (Epsilon 1-8D, Martin Christ, Osterode am Harz, Germany) at 0.450 mbar vacuum, with a pre-freezing temperature of $-40{ }^{\circ} \mathrm{C}$ and drying temperature of $20^{\circ} \mathrm{C}$ for $48 \mathrm{~h}$.

\subsection{Recovery of Freeze-Dried Cells and Cell Viability Determination}

The freeze-dried cell samples were reconstituted to their original pre-freeze-dried volumes by adding M17 broth and incubating at $37^{\circ} \mathrm{C}$ for $1 \mathrm{~h}$. For cell viability determination, serial decimal dilutions of each reconstituted sample $\left(10^{-1}\right.$ to $\left.10^{-6} \mathrm{CFU} / \mathrm{mL}\right)$ in $\mathrm{M} 17$ broth were prepared and plated onto M17 agar plates, which were then incubated at $37^{\circ} \mathrm{C}$ for $24 \mathrm{~h}$. Colonies on the plate were counted and represented as colony-forming unit per volume (CFU/mL) [16]. Survival rate (\%) after the freeze-drying process was calculated as follows [37]:

$$
\text { Survival rate }(\%)=\frac{\mathrm{N}_{\mathrm{o}}-\left(\mathrm{N}_{\mathrm{o}}-\mathrm{N}\right)}{\mathrm{N}_{\mathrm{o}}} \times 100 \%
$$

where $\mathrm{N}$ is the viable cell count after freeze-drying (FD) $(\mathrm{CFU} / \mathrm{mL}) ; \mathrm{N}_{\mathrm{o}}$ is the viable cell count before $\mathrm{FD}(\mathrm{CFU} / \mathrm{mL})$; FD represents freeze-drying.

\subsection{Antifungal Activity}

P. polymyxa Kp10 was screened for its in vitro antifungal activity against C. gloeosporioides and C. truncatum using a dual culture test based on the percentage of inhibition of radial growth (PIRG) [44]. A mycelia agar disc, $5 \mathrm{~mm}$ in length, from a 5-day-old culture was placed at the center of a Petri dish containing potato dextrose agar (PDA) medium. Plates were incubated at $27^{\circ} \mathrm{C}$ for $48 \mathrm{~h}$. A loopful of P. polymyxa Kp10 from $24 \mathrm{~h}$ of M17 agar plate culture was taken and streaked in a $3 \mathrm{~cm}$ circle from the mycelia agar disc on the same PDA plate and incubated for 5 days. P. polymyxa Kp10 in freeze-dried 
powder form was tested in the assay. Data for PIRG was recorded during the incubation period by measuring the radius of $C$. gloeosporioides and $C$. truncatum agar disc using the following formula:

$$
\text { Percentage of inhibition of radial growth }(P I R G)=\frac{R 1-R 2}{R 1} \times 100 \%
$$

where $R 1$ indicates the radial growth of fungal agar disc in the control plate; $R 2$ refers to the radial growth of the fungal agar disc in the dual culture plate [41].

\section{Conclusions}

In conclusion, the cell viability of P. polymyxa Kp10 after freeze-drying could be improved using an optimal concentration of protective agents. The optimal combination was found to be a mixture of lactose $(10 \% w / v)$ and sucrose $(27.5 \% w / v)$ that resulted in $5.839 \log C F U / \mathrm{mL}$ after freeze-drying. P.polymyxa Kp10 has proved to inhibit fungal phytopathogens through a dual culture test with the potential to be used as a biofungicide. Nevertheless, this study requires further works focusing on P. polymyxa Kp10 as a biofungicide in crop plantation to determine the stability of freeze-dried P. polymyxa Kp10 during field applications.

Author Contributions: Conceptualization, H.S.N., M.H., and N.A.A.R.; data curation, H.S.N., H.M.Y., M.H., and N.A.A.R.; formal analysis, H.S.N., M.H., and N.A.A.R.; funding acquisition, N.A.A.R.; investigation, H.S.N.; methodology, H.S.N., M.H., and N.A.A.R.; project administration, N.A.A.R.; resources, M.H. and N.A.A.R.; software, H.M.Y.; supervision, M.H. and N.A.A.R.; validation, H.M.Y., M.H., and N.A.A.R.; visualization, H.S.N. and H.M.Y.; writing-original draft, H.S.N.; writing-review and editing, H.M.Y., M.H., and N.A.A.R. All authors have read and agreed to the published version of the manuscript.

Funding: This research received no external funding.

Acknowledgments: The authors would like to thank Universiti Putra Malaysia for the financial support given.

Conflicts of Interest: The authors declare no conflicts of interest.

\section{References}

1. Yashoda, K.; Manasa, M.; Vivek, M.N.; Prashith Kekuda, T.R. Inhibitory Effect of Some Plants of Western Ghats of Karnataka against Colletotrichum capsici. Sci. Technol. Arts Res. J. 2014, 3, 76. [CrossRef]

2. Yusuf, N.; Fazi, S.M.; Ali, N.A.; Fauzi, N.I. Effects of Colletotrichum capsici infection on the growth and antioxidative response on defense mechanisms of Capsicum annuum. Malays. J. Microbiol. 2016, 12, 455-462.

3. Bale, J.; van Lenteren, J.; Bigler, F. Biological control and sustainable food production. Philos. Trans. R. Soc. B Biol. Sci. 2008, 363, 761-776. [CrossRef]

4. Timmusk, S.; West, P.V.; Gow, N.A.R.; Huffstutler, R.P. Paenibacillus polymyxa antagonizes oomycete plant pathogens Phytophthora palmivora and Phythium aphanidermatum. J. Appl. Microbiol. 2009, 106, 1473-1481. [CrossRef] [PubMed]

5. Weselowski, B.; Nathoo, N.; Eastman, A.W.; Macdonald, J.; Yuan, Z.C. Isolation, identification and characterization of Paenibacillus polymyxa CR1 with potentials for biopesticide, biofertilization, biomass degradation and biofuel production. BMC Microbiol. 2016, 16, 244. [CrossRef] [PubMed]

6. Deng, Y.; Lu, Z.; Lu, F.; Zhang, C.; Wang, Y.; Zhao, H.; Bie, X. Identification of LI-F type antibiotics and di-n-butyl phthalate produced by Paenibacillus polymyxa. J. Microbiol. Meth. 2011, 85, 175-182. [CrossRef] [PubMed]

7. Lal, S.; Tabacchioni, S. Ecology and biotechnological potential of Paenibacillus polymyxa: A mini review. Indian J. Microbiol. 2009, 49, 2-10. [CrossRef]

8. Grady, E.N.; MacDonald, J.; Liu, L.; Richman, A.; Yuan, Z.-C. Current knowledge and perspectives of Paenibacillus: A review. Microb. Cell Fact. 2016, 15, 203. [CrossRef]

9. Liu, Z.; Wei, H.; Li, Y.; Li, S. Optimization of the spray drying of a Paenibacillus polymyxa-based biopesticide on pilot plant and production scales. Biocontrol Sci. Technol. 2014, 24, 37-41. [CrossRef]

10. Du, N.; Shi, L.; Yuan, Y.; Sun, J.; Shu, S.; Guo, S. Isolation of a potential biocontrol agent Paenibacillus polymyxa NSY50 from vinegar waste compost and its induction of host defense responses against Fusarium wilt of cucumber. Microbiol. Res. 2017, 202, 1-10. [CrossRef] [PubMed] 
11. Allard, S.; Enurah, A.; Strain, E.; Millner, P.; Rideout, S.L.; Brown, E.W.; Zheng, J. In situ evaluation of Paenibacillus alvei in reducing carriage of Salmonella enterica serovar newport on whole tomato plants. Appl. Environ. Microbiol. 2014, 80, 3842-3849. [CrossRef] [PubMed]

12. Otero, M.C.; Espeche, M.C.; Nader-Macías, M.E. Optimization of the freeze-drying media and survival throughout storage of freeze-dried Lactobacillus gasseri and Lactobacillus delbrueckii subsp. delbrueckii for veterinarian probiotic applications. Process Biochem. 2007, 42, 1406-1411. [CrossRef]

13. Halim, M.; Mohd Mustafa, N.A.; Othman, M.; Wasoh, H.; Kapri, M.R.; Ariff, A.B. Effect of encapsulant and cryoprotectant on the viability of probiotic Pediococcus acidilactici ATCC 8042 during freeze-drying and exposure to high acidity, bile salts and heat. LWT Food Sci. Technol. 2017, 81, 210-216. [CrossRef]

14. Oslan, S.N.H.; Halim, M.; Ramle, N.A.; Saad, M.Z.; Tan, J.S.; Kapri, M.R.; Ariff, A.B. Improved stability of live attenuated vaccine gdhA derivative Pasteurella multocida B:2 by freeze drying method for use as animal vaccine. Cryobiology 2017, 79, 1-8. [CrossRef] [PubMed]

15. Berner, D.; Viernstein, H. Effect of protective agents on the viability of Lactococcus lactis subjected to freeze-thawing and freeze-drying. Sci. Pharm. 2006, 74, 137-149. [CrossRef]

16. Ming, L.C.; Rahim, R.A.; Wan, H.Y.; Ariff, A.B. Formulation of Protective Agents for Improvement of Lactobacillus salivarius I 24 Survival Rate Subjected to Freeze Drying for Production of Live Cells in Powderized Form. Food Bioprocess Technol. 2009, 2, 431-436. [CrossRef]

17. Bircher, L.; Geirnaert, A.; Hammes, F.; Lacroix, C.; Schwab, C. Effect of cryopreservation and lyophilization on viability and growth of strict anaerobic human gut microbes. Microb. Biotechnol. 2018, 11, 721-733. [CrossRef]

18. Zhang, B.; Hui, Y.; Chen, H.; Wan, H. Optimization of cryoprotectants for Streptococcus thermophilus during freeze-drying using Box-Behnken experimental design of response surface methodology. Emir. J. Food Agric. 2017, 29, 256-263.

19. Carvalho, A.; Teixeira, P.; Gibbs, P.; Carvalho, A.S.; Silva, J.; Ho, P.; Teixeira, P.; Malcata, F.X.; Gibbs, P. Relevant factors for the preparation of freeze- dried lactic acid bacteria. Int. Dairy J. 2004, 14, 835-847. [CrossRef]

20. Oslan, S.N.H.; Tan, J.S.; Saad, M.Z.; Halim, M.; Mohamed, M.-S.; Ariff, A.B. Influence of amino acids and vitamins on the growth of gdhA derivative Pasteurella multocida B:2 for use as an animal vaccine. Bioprocess Biosyst. Eng. 2019, 42, 355-365. [CrossRef]

21. Othman, M.; Ariff, A.B.; Wasoh, H.; Kapri, M.R.; Halim, M. Strategies for improving production performance of probiotic Pediococcus acidilactici viable cell by overcoming lactic acid inhibition. AMB Express 2017, 7, 215. [CrossRef] [PubMed]

22. Ming, L.C.; Halim, M.; Rahim, R.A.; Wan, H.Y.; Ariff, A. Bin Strategies in fed-batch cultivation on the production performance of Lactobacillus salivarius I 24 viable cells. Food Sci. Biotechnol. 2016, 25, 1393-1398. [CrossRef] [PubMed]

23. Rojas Tapias, D.; Ortiz-Vera, M.; Rivera, D.; Kloepper, J.; Bonilla, R. Evaluation of three methods for preservation of Azotobacter: Freeze-drying, cryopreservation, and immobilization in dry polymers. Univ. Sci. 2013, 18, 129-139. [CrossRef]

24. Keivani, F.; Mokarram, R.R.; Benis, K.Z.; Gholian, M.M.; Zendeboodi, F.; Zadeh, S.S. External and internal factors affecting survival of probiotic living cells during desiccation. Int. J. Pharm. 2014, 3, 309-316.

25. Kim, Y.S.; Kotnala, B.; Kim, Y.H.; Jeon, Y. Biological characteristics of Paenibacillus polymyxa GBR-1 involved in root rot of stored Korean ginseng. J. Ginseng Res. 2016, 40, 453-461. [CrossRef]

26. Corcoran, B.M.; Ross, R.P.; Fitzgerald, G.F.; Stanton, C. Comparative survival of probiotic lactobacilli spray-dried in the presence of prebiotic substances. J. Appl. Microbiol. 2004, 96, 1024-1039. [CrossRef]

27. Mary, P.; Ochin, D.; Tailliez, R. Growth status of rhizobia in relation to their tolerance to low water activities and desiccation stresses. Soil Biol. Biochem. 1986, 18, 179-184. [CrossRef]

28. Chen, H.; Tian, M.; Chen, L.; Cui, X.; Meng, J.; Shu, G. Optimization of composite cryoprotectant for freeze-drying Bifidobacterium bifidum BB01 by response surface methodology. Artif. Cells, Nanomed. Biotechnol. 2019, 47, 1559-1569. [CrossRef]

29. You, Q.; Peng, J.; Xie, Y.; Xin, L.; Zhiguang, T.; Feng, B.; Wang, L.; Weng, M.; Ganlin, C. Optimization of Protective Agents and Freeze-Drying Conditions for Lactobacillus casei LT-L614. J. Biobased Mater. Bioenergy 2019, 13, 123-128. [CrossRef] 
30. Dianawati, D.; Mishra, V.; Shah, N.P. Survival of Bifidobacterium longum 1941 microencapsulated with proteins and sugars after freezing and freeze drying. Food Res. Int. 2013, 51, 503-509. [CrossRef]

31. King, V.A.E.; Su, J.T. Dehydration of Lactobacillus acidophilus. Process Biochem. 1993, 28, 47-52. [CrossRef]

32. Hubálek, Z. Protectants used in the cryopreservation of microorganisms. Cryobiology 2003, 46, $205-229$. [CrossRef]

33. Portner, D.C.; Leuschner, R.G.K.; Murray, B.S. Optimising the viability during storage of freeze-dried cell preparations of Campylobacter jejuni. Cryobiology 2007, 54, 265-270. [CrossRef] [PubMed]

34. Shamekhi, F.; Shuhaimi, M.; Ariff, A.B.; Yazid, A.M. Optimization of a cryoprotective medium for infant formula probiotic applications using response surface methodology. Ann. Microbiol. 2012, 62, 911-921. [CrossRef]

35. Morgan, C.A.; Herman, N.; White, P.A.; Vesey, G. Preservation of micro-organisms by drying; A review. J. Microbiol. Methods 2006, 66, 183. [CrossRef]

36. Piszkiewicz, S.; Pielak, G.J. Protecting Enzymes from Stress-Induced Inactivation. Biochemistry 2019, 58, 3825-3833. [CrossRef]

37. Wong, S.; Kabeir, B.M.; Mustafa, S.; Mohamad, R.; Hussin, A.S.M.; Manap, M.Y. Viability of Bifidobacterium Pseudocatenulatum G4 after Spray-Drying and Freeze-Drying. Microbiol. Insights 2010, 3, 37-43. [CrossRef]

38. Song, W.; Ma, D.; Wei, X. Original Research Article Assessing cell viability and biochemical stability of freeze-dried Sulphate-Reducing bacteria within different types of cryoprotectants and storage conditions. Int. J. Curr. Microbiol. Appl. Sci. 2014, 3, 659-670.

39. Naing, K.W.; Anees, M.; Kim, S.J.; Nam, Y.; Kim, Y.C.; Kim, K.Y. Characterization of antifungal activity of Paenibacillus ehimensis KWN38 against soilborne phytopathogenic fungi belonging to various taxonomic groups. Ann. Microbiol. 2014, 64, 55-63. [CrossRef]

40. Chen, X.; Wang, G.; Xu, M.; Jin, J.; Liu, X. Antifungal peptide produced by Paenibacillus polymyxa BRF-1 isolated from soybean rhizosphere. African J. Microbiol. Res. 2010, 4, 2692-2698.

41. Jeong, H.; Choi, S.K.; Ryu, C.M.; Park, S.H. Chronicle of a soil bacterium: Paenibacillus polymyxa E681 as a Tiny Guardian of Plant and Human Health. Front. Microbiol. 2019, 10, 1-16. [CrossRef] [PubMed]

42. Karpunina, L.V.; Mel'nikova, U.Y.; Konnova, S.A. Biological role of lectins from the nitrogen-fixing Paenibacillus polymyxa strain 1460 during bacterial-plant-root interactions. Curr. Microbiol. 2003, 47, 376-378. [CrossRef] [PubMed]

43. Raza, W.; Hongsheng, W.; Qirong, S. Response of Paenibacillus polymyxa to iron: Alternations in cellular chemical composition and the production of fusaricidin type antimicrobial compounds. Brazilian Arch. Biol. Technol. 2010, 53, 1145-1154. [CrossRef]

44. Begum, M.M.; Sariah, M.; Abidin, M.A.Z.; Puteh, A.B.; Rahman, M.A. Antagonistic potential of selected fungal and bacterial biocontrol agents against Colletotrichum truncatum of soybean seeds. Pertanika J. Trop. Agric. Sci. 2008, 31, 45-53.

Sample Availability: Samples of the bacteria are not available from the authors.

(C) 2020 by the authors. Licensee MDPI, Basel, Switzerland. This article is an open access article distributed under the terms and conditions of the Creative Commons Attribution (CC BY) license (http://creativecommons.org/licenses/by/4.0/). 